\title{
Oppressive Faces of Whiteness in Walter Mosley's Devil in a Blue Dress
}

\section{ABSTRACT}

Walter Mosley's Devil in a Blue Dress contributes significantly to the literary debate on the definition of whiteness. The socio-historical construction of whiteness emerging from the novel is amplified by white imagery dovetailing with the claims made about white people directly. For the African American first person narrator, Easy Rawlins, living in postWorld War II Los Angeles, whiteness mostly spells terror. The oppressive faces of whiteness consist in the following trajectories: property relations, economic exploitation, labour relations, the legal system, different miens of oppressive white masculinity denigrating blackness, spatial dynamics of post-World War II Los Angeles and the white apparatus of power that the narrator needs to confront throughout the novel. White imagery carried to the extreme magnifies the terrorizing aspect of whiteness in the narrative. Like many authors of colour, Mosley associates whiteness with death. Whiteness inundates Easy Rawlins from all sides, entailing insincerity, dishonesty, interestedness and hypocrisy.

Keywords: Walter Mosley, Devil in a Blue Dress, whiteness, white oppression, white imagery. 
Walter Mosley's Devil in a Blue Dress contributes significantly to the literary debate on the definition of whiteness. The socio-historical construction of whiteness emerging from the novel is amplified by white imagery dovetailing with the claims made about white people directly. For the African American first person narrator, Easy Rawlins, living in post-World War II Los Angeles, whiteness mostly spells terror. The oppressive faces of whiteness consist in the following trajectories: property relations, economic exploitation, labour relations, the legal system, different miens of oppressive white masculinity denigrating blackness, spatial dynamics of post-World War II Los Angeles and the white apparatus of power that the narrator needs to confront throughout the novel. White imagery carried to the extreme magnifies the terrorizing aspect of whiteness in the narrative. Like many authors of colour, Mosley associates whiteness with death. Whiteness inundates Easy Rawlins from all sides, entailing insincerity, dishonesty, interestedness and hypocrisy.

The literary debate on whiteness in American literature, in which Walter Mosley's Devil in a Blue Dress inscribes itself, was initiated long before whiteness studies became established as a scholarly discipline. American writers who incorporated the analysis of whiteness in their works as a trope date as far back as early African American slave narratives, for example Olaudah Equiano's The Interesting Life of Olaudah Equiano (1789), and later African American slave narratives, such as Frederick Douglass's A Narrative of the Life of Frederick Douglass, an American Slave (1845) and Harriet Jacobs's Incidents in the Life of a Slave Girl. Written by Herself (1861), as well as Elizabeth Keckley's Behind the Scenes: Or, Thirty Years a Slave and Four Years in the White House (1868). It is even more essential to acknowledge those African American authors who can be credited with setting the foundations of the discipline before whiteness studies emerged as a separate field of study. This is a selected list of works by African American authors who were the first to consciously reflect on the construction of whiteness: Charles Waddell Chesnutt's "What Is a White Man" (1889); W. E. B. Du Bois's "The Souls of White Folk" (1920) in which he declares himself "singularly clairvoyant" of white souls: "I see in and through them. I view them from unusual points of vantage. ... I see these souls undressed and from the back and side. . . I see them ever stripped-ugly, human" (923); Du Bois's "The White World" (1940); Richard Wright's "Introduction" to Black Metropolis (1945); James Baldwin's Notes of a Native Son (1955); Ralph Ellison's essays collected in Shadow and Act (1964); Black nationalists' writings, for example those by Sam Greenlee, George Jackson, Amiri Baraka, Eldridge Cleaver, Malcolm X and Stokely Carmichael. All of the authors named above look at a whole myriad of issues involving whiteness, such as the hypocrisy of whites, the financial motives behind the persisting colour line, the fear of miscegenation, the absurdity of anti-miscegenation laws, 
and the double consciousness of white people, to mention only some of the themes recurring in the works cited above.

In 1992 Toni Morrison inaugurated contemporary North American literary whiteness studies with her seminal work Playing in the Dark, in which she examines the construction of whiteness and blackness in canonical and non-canonical works of American literature. Expounding the purpose of her study, Morrison states: "My project is to avert the critical gaze from the racial object to the racial subject, from the described and imagined to the describers and imaginers, from the serving to the served" (90). The reversal of the gaze was simultaneously performed in sociology, history, legal studies and film studies. One year before the publication of Morrison's Playing in the Dark David Roediger published The Wages of Whiteness (1991), analyzing the white working class mentality and its policies. Other whiteness scholars to whom I am particularly indebted in the research on whiteness in American ethnic literature are Ruth Frankenberg, Cheryl Harris, Robyn Wiegman, George Lipsitz, Linda Frost, Valerie Babb and Gary Taylor. All of them underscore the socio-historical construction of whiteness, exposing white people's attachment to the privileges accruing to their whiteness.

The following exploration of whiteness in Walter Mosley's Devil in a Blue Dress delves into different facets of white oppression in relation to such spheres as the law, the economy, space, white imagery and white masculinity. The terror of whiteness comes to life for the first person narrator of the novel, Easy Rawlins, in the figures of a white gangster, DeWitt Albright, a white policemen, a white employer, Benny Giacomo, a white businessman, Carter and racist white youths, who see Easy Rawlins as a threat to white womanhood. Almost all of these figures represent a different face of white terror, posing a threat to Easy's integrity. Whiteness displays its most brutal faces during Easy's confrontations with the law-both its white guardians and its trespassers. The white gangster, DeWitt Albright, is an embodiment of brutal white power that demands unquestioning obedience. His emblematic whiteness is accentuated by the colour of his skin, his complexion, eyes and dress:

It's not just that he was white but he wore an off-white linen suit and shirt with a Panama straw hat and bone shoes over flashing white silk socks. His skin was smooth and pale with just a few freckles.... He surveyed the room with pale eyes; not a color I'd ever seen in a man's eyes....

There was a white leather shoulder holster under his left arm. ...

The butt and the barrel [of the gun] were black; the only part of DeWitt's attire that wasn't white. (1,18, emphasis added) 
Easy draws the above portrayal of DeWitt Albright at the very beginning of their acquaintance, sensing an air of danger around the white man who suddenly enters his life. The opening passage of the novel is dedicated to Albright's depiction, as if setting the stage for the development of the plot based to a great extent on the ramifications of Easy's and Albright's liaison. A significant detail of Easy's portrayal of Albright is the moment when Easy reflects on Albright's pale eyes, noting that he has never seen such colour "in a man's eyes" (1). This subtle observation on the nonhuman colour of Albright's eyes sets him apart from the rest of humanity, foreshadowing his brutal, unscrupulous character that becomes apparent in the unfolding narrative. After being proved right in his premonitions about DeWitt Albright, Easy observes that "his dead eyes turned colder" (100). This metonymic approach to whiteness appears again in the novel when Easy states that he is tired of "strange white men with dead blue eyes" (63). Beyond the most obvious associations of death, "dead blue eyes" conjure up a lack of depth, coldness, lack of involvement and a kind of dehumanization, if one assumes that eyes are the mirror of the soul. Most of these associations of whiteness are grounded in Easy's own experiences with white people or the experiences of other African Americans with whom he interacts. In "Walter Mosley's Easy Rawlins: The Detective and Afro-American Fiction," Theodore Mason calls Albright "a real white devil" (174). The phrase "devil" was often applied to whites by black nationalists, but African Americans were by no means the only racial group to use the term. So did Asian Americans, interweaving "devils" with "demons," "barbarians" and "savages."

While Albright immediately instils a sense of trepidation and extreme caution in Easy, he does not initially reveal his unscrupulous demeanour, even going to the point of sympathizing with Easy when he learns about the loss of his factory job and an unpaid mortgage instalment:

These big companies don't give a damn about you. The balance doesn't balance just right and they let ten family men go.... The only thing that's worse than a big company is the bank. They want their money on the first and if you miss the payment, they will have the marshal knocking down your door on the second. $(3,4)$

1 I discuss the problem of the representation of white people in Asian American literature in Visions of Whiteness in Selected Works of Asian American Literature. In the chapter devoted to Maxine Hong Kingston's China Men, I trace the application of metaphysical condensation, metonymic displacement and colour coding to at least some whites featuring in Kingston's work. All of the above mentioned techniques were discussed by Toni Morrison in Playing in the Dark. 
Albright's later interaction with Easy reveals that he approximates big companies and banks in their unswerving expectations to deliver results and his punishment for failure is death.

Another face of terrorizing whiteness operating outside the perimeter of the law is revealed during Easy's casual encounters with whites in the rich neighbourhoods in which he feels uncomfortable because they are inhabited exclusively by white people and as a black man he is not supposed to be there although he is not legally excluded through any legal ordinance. His very presence in exclusively white districts of Los Angeles suffices to produce in whites anxiety and suspicion of mischief on the part of an uninvited black interloper. Easy encounters the reaction of pronounced hostility from white you ths when they see him talk to a white woman in Santa Monica. Although Barbara is the initiating part in the conversation and she vociferously takes to Easy's defence, white aggressive youths perceive him as a predator encroaching upon white womanhood defined as the exclusive domain of white men. They refer to white women as if they were their possessions, reducing them to the position of mute objects incapable of interpreting reality: "We don't need ya talking to our women. . . . Nigger's trying to pick up Barbara" (53, 54, emphasis added). At one point the offending youth addresses Easy as "boy," while Easy calls him "man" (54). An insight into Easy's thoughts shows that he refrains from responding to threats of violence with violence despite physical superiority over the belligerent youths, "white kids" as he designates them. In his portrayal of one of the youths Mosley reaches for the strategy often employed by white authors depicting African American characters, the strategy characterized by Toni Morrison in Playing in the Dark as metonymic displacement or colour coding (80). Under this strategy African Americans were seen almost exclusively through the prism of their racial difference. Depicting the white youth, Easy draws the reader's attention to various elements of the youth's physicality, but all of them play second fiddle to his essentialized whiteness: "His eyes, nose, and mouth were like tiny islands on a great sea of white skin" (Mosley 54). While colour coding in white American authors' narratives discussed by Morrison did not have its grounding in any oppression encountered from African Americans but rather in a sense of their insignificance or in the stereotypes passed from generation to generation, what Morrison terms the "economy of stereotype" (67), Easy's portrayal of the verbally aggressive young man is dictated by his own oppression suffered at the hands of whites and by the fact that the offensive youths reduce the unfolding conversation to the question of racial difference as the crux of the problem that Easy presents to them.

The most graphic revelations of whiteness come during Easy's interactions with the police. This is because the whiteness in question is 
the whiteness sanctified by the law and ironically those who are supposed to represent the law and be paragons of justice commit the most flagrant and violent acts against the African American subject's mental and bodily integrity, blatantly floundering all rules of fair investigation and interrogation, as well as openly declaring to Easy that he is helpless in confrontation with the United States system of justice because whatever they decide is sacred and Easy has no formal legal recourse that he can rely on. The following citations demonstrate the helplessness of an average African American man at the turn of the 1940s and 1950s faced with the legal and penal machinery:

"I've got the right to know why you're taking me." "You got a right to fall down and break your face, nigger. You got a right to die," he said. Then he hit me in the diaphragm.... "Means we can take your black ass out behind the station and put a bullet in your head." $(68,72)$

The violence cited above is only a part of the brutal treatment that Easy receives during the interrogation. Meditating the killing of the policemen, he does not fight back, using only the evasion tactics that partly mitigate his injuries, still leaving him in a pitiable condition. Hitting back is not an option if he is to remain a free black man and a man of property, which Easy clearly cherishes above everything else. The other option is to enter his car and drive away from Los Angeles, the option that he does not choose because this would mean running away, starting anew, parting with his beloved house. In Easy's eyes, leaving would compromise his manhood, as well as cast a shadow of doubt upon his courage and resourcefulness: "Leave! Leave? You gonna run away from the only piece'a property you ever had?... . Better be dead than leave" (96). Thomas Michael Stein looks at Easy's reticent subjection to the violent police interrogation through the prism of capitalist relations: "This kind of violence ... also teaches Rawlins to accept the principles of capitalism" (201). As an African American man in debt and with no connections to white people in positions of power at the time when he is interrogated, Easy is in no position to physically resist. ${ }^{2}$

2 Capital may still play a lesser role than the question of racial difference if one considers a similar case of police brutality taking place in the Black Betty sequel of the Easy Rawlins series. Although by then Easy has managed to amass vast capital, he still remains vulnerable to police violence: "Six men! Policemen. There were around the car and in the doors before I could even think. I was dragged from the front seat and thrown to the asphalt. ... 'Hey, man! What'd I do,' I shouted. That got me a nightstick pressed hard across the back of my neck. ... A big knot had swollen up above my diaphragm and my side ached awfully. He must have hit me after I was out. That's the only way I could understand it, all those bumps and 
An equivalent situation of helplessness in confrontation with the police occurs in one of the final scenes of the novel when Easy's momentary elation at being free is once again crushed by the police threats that unless he provides them with information they can shift blame to him by planting evidence.

As limited as Easy's physical response to the racial profiling by the police can be, no one is able to in any way control his mental reaction to the restriction of his freedom and the ensuing police violence. Looking around the bare, scruffy cell, he realizes that whatever evidence the police have against him, he could do barely anything to challenge it: "it didn't matter as long as they thought they were right" (70). It is not accidental that, reflecting on his own circumstances, Easy suddenly starts to ponder on the fate of a dead mouse that he can see on the other side of the cell in a corner. The analogies between his own situation and that of the dead mouse are all too apparent. He too is cornered like a dead mouse with limited possibilities of escape. ${ }^{3}$ The prison scene highlights what whiteness studies scholar Robyn Wiegman calls the "panoptic power of whiteness" (119). This panoptic power of whiteness becomes conspicuous to Easy when he can hear the cell door being opened. It is then that he chastises himself for not checking if the door was locked: "I was angry at myself because I hadn't tried to see if the door was locked. Those cops had me where they wanted me" (Mosley 70). The dynamics change after the violent police interrogation. Easy no longer identifies with the mouse but imagines that one of the police officers is the mouse that he crushes to death: "This time, though, I imagined that I was the convict and the mouse was officer Mason. I crushed him so that his whole suit was soiled and shapeless in the corner; his eyes came out of his head" (74). During his incarceration, whiteness has a bipolar relation to blackness. On the one hand, Easy is assailed by whiteness represented by white cops, while on the other hand, in his cell he is surrounded by all-encompassing blackness with which he would like to merge in order to escape his captors. Blackness is represented by the nighttime:

bruises" (Black Betty 125). Although the action of Black Betty published in 1994 unfolds in the 1960s, several decades before the Rodney King violent police action of 1991 and the acquittal of four white policemen in 1992, the above cited passage bears close reminiscence to the so-called "Rodney King incident."

3 In Native Son Richard Wright applies a similar metaphor to render Thomas Bigger's frustration and his sense of being cornered. The animal illustrating Bigger's state of mind is a rat. Still, unlike the first-person narrator, Easy Rawlins, Thomas Bigger is not an articulate or fully conscious character. The third-person narrator needs to translate his thoughts to the reader. 
All I did was sit in darkness, trying to become the darkness. I was awake but my thinking was like a dream. I dreamed in my wakefulness that I could become the darkness and slip out between the eroded cracks of the cell. If I was nighttime nobody could find me; no one would even know I was missing. (74)

The passage clearly establishes an intertextual connection to Ralph Ellison's Invisible Man, in which the protagonist is often suspended between dreaming and wakefulness and at a certain point he also starts to utilize both the shielding power of his invisibility and the cover of darkness to protect himself. Easy overtly employs the term "invisibility" while relishing the fact that he is an invisible detective because no one knows that he investigates the case:

Nobody knew what I was up to and that made me sort of invisible; people thought that they saw me but what they really saw was an illusion of me, something that wasn't real.... I never got bored or frustrated. I wasn't even afraid of DeWitt Albright during those days. I felt, foolishly, safe from even his crazy violence. (128)

Both the "nighttime" invisibility and the invisibility of his investigation provide Easy with a clear sense of protection.

In the light of the tribulations that Easy and other African Americans endure with the executive branch of the legal system, he concludes that there is no justice for African Americans at the turn of 1950. The only justice they can procure is the justice that they can purchase:

I got the idea, somehow, that if I got enough money then maybe I could buy my own life back. But I didn't believe that there was justice for Negroes. I thought that there might be some justice for a black man if he had the money to grease it. Money isn't a sure bet but it's the closest to God that I've ever seen in this world. (121)

Mouse's (Easy's black friend) innuendo to the police parallels the above statement. According to Mouse, any poor black man is likely to fall prey to the American penal system. Ironically, African American views on the American system of justice are seconded by its chief trespasser in the novel, DeWitt Albright, one of the most terrorizing faces of whiteness drawn in the narrative. According to Albright, rich people construct the law in such a way that poor people cannot advance socially: "The law ... is made by the rich people so that the poor people can't get ahead" (20).

The most serious charge levelled at the American justice system comes from Easy when he notes that no one displays any concern for 
non-white victims of crime, suggesting that the lives of people of colour are not highly valued by the rest of society: "The police didn't care about crime among Negroes.... The papers hardly ever even reported a colored murder. And when they did it was way in the back pages" (160). What remains unstated directly by the first-person narrator of Devil in a Blue Dress, yet what is clearly implied to the reader is the conclusion that the law presented in the narrative world of the turn of 1950 is the white law. Walter Mosley's characterization of the American justice system corresponds to his wider portrayal of socio-historical problems and is best summed up in Marilyn C. Wesley's words: "Walter Mosley represents rather than resolves complicated historical issues of the multiracial society Easy uncomfortably inhabits" (114). Mark L. Berrettini observes that eponymous Daphne Monet brings up the echoes of a real-life woman, Elizabeth Short, murdered in Los Angeles in 1947. The police nicknamed Ms Short "Black Dahlia," reducing her to a loose woman whose tortured death was not worth investigating (Berrettini 76).

The oppressive face of whiteness does not only assume the form of physical aggression in the novel, but also of economic hegemony which is equally arduous to people of colour. The Los Angeles aircraft company from which Easy is fired highlights the position of African Americans in the American economy, replicating the Southern plantation system and, to some extent the ideology, of chattel slavery. Easy compares his Italian American boss, Benito (Benny) Giacomo, to the white plantation owner, who looks at the workers as at potentially disobedient, lazy children lacking responsibility and therefore in constant need of censure and supervision:

A job in a factory is an awful lot like working on a plantation in the South. The bosses see all the workers like they're children, and everyone knows how lazy children are. So Benny thought he'd teach me a little something about responsibility because he was the boss and I was the child. (Mosley 62)

Like slave masters, white supervisors expect African American gratefulness and obsequiousness (65). The above cited passage bears striking correspondence to Charles Waddell Chesnutt's characterization of southern paternalism in "The Passing of Grandison." This is how the third person narrator of Chesnutt's story eulogizes southern paternalism, focalizing the narration through Colonel Owen's point of view:

[Colonel Owen's] feudal heart thrilled at such appreciative homage [from Grandison]. What cold-blooded, heartless monsters they [abolitionists] were who would break up this blissful relationship of kindly protection on the one hand, of wise subordination and loyal dependence on 
the other!. . . . [Grandison] so sensibly recognized his true place in the economy of civilization, and kept it with such touching fidelity? (Chesnutt 5, 8)

While Grandison ostensibly "recognized his true place in the economy of civilization" and therefore managed to trick his credulous slave master, Easy Rawlins refuses to accept his true place in the economy of the end of the 1940s United States and therefore loses his job in the aircraft manufacturing company and needs to reach for extra-legal means to gain the funds for the repayment of his mortgage. Staying within the bounds of strictly legal activity, Easy has practically no economic agency. He can only be an overworked labourer straining his physical capacities in order to pay off the mortgage and keep the house. As his redundancy on the white boss's whim demonstrates, this insignificant position in the American economic ladder is by no means guaranteed. Like a slave owner, Giacomo expects Easy to cower before him: "He [Giacomo] needed all his children to kneel down and let him be the boss. He wasn't a businessman, he was a plantation boss; a slaver" (Mosley 66). Nicole King observes that "without compromising his racial integrity and pride, Easy cannot even keep his job in the factory" (221). King goes on to say that although Easy's ancestors, both slaves and sharecroppers, as well as Easy himself, a former soldier and factory labourer, significantly contributed to "generat[ing] and multipl[ying] the nation's wealth,” Easy, as a black American citizen, reaps very meagre economic rewards from the capital that African Americans helped to produce (221). Stereotypes about African American laziness and their professional inaptitude surface in Giacomo's disparaging comments about African American workers: "And he had the nerve to tell me that my people have to learn to give a little extra if we wanna advance.' ... I told him that my people been givin' a little extra since before Italy was even a country" (Mosley 29, emphasis original). The application of the term "[your] people" by Giacomo exemplifies ethnocentrism and conventional identity politics prioritizing the experience of one racial or ethnic group over that of another. Easy's accentuation of the term "my people" underlines his indignation at Giacomo's remarks and is further amplified by his terse rejoinder.

Giacomo's antagonistic attitude towards African Americans exposes other aspects of the ideology of whiteness. First of all, Giacomo's own status as a white man underscores the constructedness of all racial categories. Despite having a fairly dark complexion, he is still classified as white: "His salt-and-pepper hair had once been jet black and his skin color was darker than many mulattos I'd known. But Benny was a white man and I was a Negro” (65). As a second-generation Italian American, 
Giacomo rises to the position of a foreman on the factory floor, but his whiteness is not nearly so well established as that of Anglo-Americans. As Ruth Frankenberg notes, "there are two kinds of whites, just as there are two kinds of Americans: those who are truly or only white, and those who are white but also something more-or is it something less?" (68). In light of Giacomo's peripheral status within the domain of whiteness, his hostility towards African American workers may be underlain not only by a stereotypical perception of black people, but also by the fragility of his own social status and reverse power dynamics that to some extent psychologically compensate for his own marginalization as an Italian American working class man. Giacomo's animosity towards African Americans could be classified as "compensatory wages of whiteness" of which W. E. B. Du Bois speaks in Black Reconstruction (700). Du Bois argues that the discrimination against black people not only gave members of the working class comparatively higher wages, but also significantly boosted their own egos. Working class whites derived ample comfort from the fact that there was still someone beneath them in the hierarchy. Exposed to class oppression, white workers were free of racial oppression and apparently that was enough to keep many of them from identifying and targeting those responsible for their exploitation and drawing the largest dividends. The result of such a reasoning on the part of the white working class was that "the wages of both classes could be kept low, the whites fearing to be supplanted by Negro labor, the Negroes always being threatened by the substitution of white labor" (Du Bois 701). Cheryl Harris observes that the white working class was much more likely to identify with the bourgeoisie than with fellow black workers, playing up their racial status rather than class identification (1741). Elaborating on Du Bois's concept of the compensatory wages of whiteness, David Roediger declares that the "status and privileges conferred by race could be used to make up for alienating and exploitative class relationships, North and South. White workers could, and did, define and accept their class positions by fashioning identities as 'not slaves' and as 'not Blacks'” (13).

The aspect which also arises in the context of the labour relations in the aircraft factory from which Easy is fired is the question of black and white masculinity. As a result of discrimination against black workers, black masculinity suffered and white masculinity received a significant boost. Discrimination against black males also fostered a bond between white workers. Easy observes no cross-racial bond between African American and white employees. He is emphatic about the fact that no white worker would be fired for standing up to Giacomo because of exhaustion: 
The white workers didn't have a problem with that kind of treatment because they didn't come from a place where men were always called boys. The white worker would have just said, "Sure, Benny, you called it right, but damn if I can see straight right now." And Benny would have understood that. He would have laughed and realized how pushy he was being and offered to take Mr. Davenport, or whoever, out to drink a beer. But the Negro workers didn't drink with Benny. We didn't go to the same bars, we didn't wink at the same girls. What I should have done, if I wanted my job, was to stay, like he asked, and then come back early the next day to recheck the work. If I had told Benny I couldn't see straight he would have told me to buy glasses. (Mosley 63)

Ironically, not being able to see straight has a broader implication in the novel. While Easy literally cannot see straight because of arduous labour conditions, Giacomo is figuratively blind, rendering African American workers metaphorically invisible, subjecting them to the process of exploitation and emasculation. Easy's invisibility to Giacomo once again echoes Ralph Ellison's Invisible Man and Invisible Man's reflections on his own invisibility to white people: "That invisibility to which I refer occurs because of a peculiar disposition of the eyes of those with whom I come in contact. A matter of the construction of their inner eyes, those eyes with which they look through their physical eyes upon reality" (3, emphasis original).

Walter Mosley juxtaposes the oppressive face of whiteness represented by the management in the aircraft factory with the oppressive face of whiteness represented by DeWitt Albright. The plot of the novel is constructed in such a way that in order to remain a man of property, a house owner, Easy needs to choose between white oppression embodied by Giacomo and that personified by Albright. Sickened by Giacomo's expectations of obsequiousness and unquestioning obedience, Easy remembers his interaction with Albright, who, despite instilling in him a sense of terror, initially seems to be much more direct and open:

I tried to think about what Benny wanted. I tried to think of how I could save face and still kiss his ass. But all I could really think about was that other office and other white man. DeWitt Albright had his bottle and his gun right out there in plain view. When he asked me what I had to say I told him; I might have been a little nervous, but I told him anyway. Benny didn't care about what I had to say. (Mosley 66)

Undertaking cooperation with Albright, Easy gains financial resources to pay the mortgage instalment, but he does not succeed in running away from the chattel system of property in which he is approached as the object of property. The employment and management structure in the aircraft 
factory may resemble the plantation system to Easy, but there is one marked difference. Slaves were not able to opt out of the system, whereas Easy can walk out of the aircraft factory a free man, limited as his spectrum of possibilities is. In the case of the cooperation with Albright, there is no walking away. When Easy offers to return Albright's money in order to terminate their cooperation, he finds out that he is reduced to an object of property belonging to Albright, who grudgingly watches his property lest it slip away: "You take my money and you belong to me" (101). Much of the critique of whiteness in the novel occurs through the exposure of racialized property relations.

Virtually all of the novel is driven by Easy's quest to defy the lawenshrined dynamic of whites as the subjects of property and African Americans as the objects of property. Easy directs most of his energy to saving his mortgage-threatened house and his own status as the subject of property and a proud property-owner, modest as his property initially is. It is hardly surprising that the white people encountered by Easy try to frustrate him in his quest to defy skewed, racist property relations of the post-World War II period, considering the socio-historical entanglement of whiteness with property. In her seminal study of racialized property relations in the United States, "Whiteness as Property," Harvard law professor Cheryl Harris argues that, historically, whiteness cautiously guarded access to property. Harris goes so far as to claim that whiteness itself has been elevated to the status of property by whites, property closely protected by its bearers. Hedging privileges reserved for whites, white people created an "exclusive club," afraid lest uninvited intruders compromise its exclusivity (Harris 1736). In a similar vein, George Lipsitz speaks of whiteness in The Possessive Investment in Whiteness in terms of a "possessive investment" in the privileges that accrue to their whiteness (1).

The dispossession of African Americans from property may at least partly account for the unique importance that Easy attaches to property ownership and wealth aggrandizement. For Easy, the son of sharecroppers, property ownership becomes a significant status marker, a benchmark according to which he calibrates his own value and manhood:

The thought of paying my mortgage reminded me of my front yard and the shade of my fruit trees in the summer heat. I felt that I was just as good as any white man, but if I didn't even own my front door then people would look at me like just another poor beggar with his hand outstretched. (Mosley 9)

Time and again he calls himself a homeowner or a man of property, spinning dreams of one day being able to live out of property lease. Easy 
admits that wealth has a mesmerizing effect on him: "The wealth made my heart beat fast" (114). As sequels to Devil in a Blue Dress reveal, financial success comes at the cost of a personal, family life and brings about the loss of a family. Still, I take issue with Liam Kennedy's claim that Easy "mortgage[s] his black identity," entering the "system of capital exchange and control" (234). Although he definitely pays the price for his aspirations, he attains financial success at the sacrifice of personal life, but not at the sacrifice of personal pride, honour or freedom. The latter is visible in his confrontation with Giacomo when he refuses to cower to him in order to save his job and in his verbal and mental repartee with Albright. To Albright's "You belong to me," he retorts "I don't belong to anybody" (Mosley 101). On another occasion he mentally asserts that "if [Albright] wanted to shoot me he'd just have to do it because I wasn't going down on my knees for him or for anybody else" (57). Part of the glee that Easy exudes at being a property owner may be related to the sense of freedom that it entails:

My chest was heaving and I felt as if I wanted to laugh out loud. My bills were paid and it felt good to have stood up for myself. I had a notion of freedom. ... I had two years' salary buried in the back yard and I was free. $(67,212)$

The epitome of owning oneself, of being one's own man is for Easy in particular home ownership. He personifies the house, approaching it as if it was a woman, employing the personal pronouns "she" and "her" to speak of the house and even prioritizing the house over any woman he has ever known:

But that house meant more to me than any woman I ever knew. I loved her and I was jealous of her and if the bank sent the county marshal to take her from me I might have come at him with a rifle rather than give her up. (11)

Attached as he is to his property, he cannot protect it from unwanted intrusions by uninvited strangers: Albright and his fellow gangsters, the police, and Frank Green. The recurrent encroachments on his property render its fragility and its affinity to its owner. Both are frail, insecure and dependent on each other.

A seemingly innocuous face of whiteness, yet one that is sinister in its own way, is represented by Todd Carter, a white businessman. Carter is a good illustration of Slavoj Žižek's term "racism with a distance" (qtd. in Prashad 61). Ensconced in his white privilege and lamenting his unfulfilled love for Daphne, Carter does not see differences in the socio-historical 
standing between people. Easy classifies Carter's as "the worst kind of racism" because "the fact that he didn't even recognize our difference showed that he didn't care one damn about me" (Mosley 119). Carter could also fall under the category of Vijay Prashad's "benevolent multiculturalist" who "treats the concept of culture as a homogeneous and ahistorical thing that can be appreciated, but that remains far outside the enclosed ambit of one's own cultural box" (61). What Prashad categorizes as "benevolent multiculturalism" resembles the definition of liberal multiculturalism that reduces differences between people to the question of different customs and underplays the economic and socio-historical differences. ${ }^{4}$ Apart from labeling Carter as the worst kind of racist, Easy questions his masculinity, labelling him a "boy" and a "child" (Mosley 115).

The racist face of whiteness is also conspicuous in the spatial dynamics depicted in Devil in a Blue Dress, both the topography of Los Angeles and the Texas-Los Angeles dichotomy, to which Mosley reverts in the narrative while discussing the characters who, like Easy, migrated from Texas to Los Angeles. Colour lines clearly mark the topography of the post-World War II Los Angeles. As already mentioned, some areas of Los Angeles are presented in the novel as de facto forbidden zones to African Americans. Venturing into those areas, especially after dark, they run the risk of being physically attacked by racist whites or being singled out by the police as potential thieves or burglars. Therefore, Easy is emphatic about entering those areas with extreme caution:

I wasn't used to going into white communities, like Santa Monica, to conduct business. The plant I worked at, Champion Aircraft, was in Santa Monica but I'd drive out there in the daytime, do my work, and go home. I never loitered anywhere except among my own people, in my own neighbourhood. $(51)^{5}$

On another occasion, while finding himself at night in a predominantly white district after being interrogated by the police, Easy wrestles with anxiety, refraining from running because "a patrol car would arrest any sprinting Negro they encountered" (76). The scene once again highlights the panoptic power of whiteness, no less ubiquitous in the open space than in the enclosed space of the prison cell.

4 For more on different types of multiculturalism: conservative, liberal and critical multiculturalism, see Peter McLaren's “White Terror and Oppositional Agency: Towards a Critical Multiculturalism.”

5 At this point Easy applies the identity politics term "my people," earlier employed by the aforementioned Giacomo. It is interesting that he chooses to do so while speaking about the invisible walls between people. 
That colour lines mark the topography of the post-World War II Los Angeles is visible not only in African American anxiety about being in almost exclusively white districts, but also in white tentativeness, if not open fear, about venturing into black districts. Aware that they are intruders in black districts or that they would not be able to enter black clubs, let alone befriend any informers, Albright and Carter need Easy to be their intermediary in the places which are off limits to them. Drawing attention to the mirror scenes of the novel, in which respectively whites and African Americans are portrayed as unwelcome in predominantly white or black spaces, Liam Kennedy notes that even if Mosley's ghetto is dystopian, it still provides refuge to black people, sheltering them at least partly from the menace posed by the white world: "[Mosley's ghetto] has its own distinctive history and patterns of life” (232). In line with Kennedy's claim, Roger A. Berger argues that Mosley reappraises the black Los Angeles, which, unlike Harlem, had been largely neglected in American culture (285).

The unique character of Mosley's ghetto stems from the fact that most of the African American characters inhabiting the black Los Angeles neighbourhood and featuring in the novel have migrated from Texas and they knew each other before moving to Los Angeles. Composing in Texas a fairly closely-knit community woven out of the similar dreams, vicissitudes and traumas, they show more fissures and estrangement from each other in Los Angeles, but they are still bound together by a sense of rootedness and mutual past. California falls far short of the visions they spun while still in Texas. African American wages in California may be higher than in Texas and there may be more profit-making opportunities, but a slightly higher standard of living comes at the cost of loosening community and family ties and African Americans still find themselves at the bottom of the economic ladder:

California was like heaven for the southern Negro. People told stories of how you could eat fruit right off the trees and get enough work to retire one day. The stories were true for the most part but the truth wasn't like the dream. Life was still hard in L.A. and if you worked every day you still found yourself on the bottom.... (27)

No matter where you live in a southern city ... you see almost everybody you know by just looking out your window. Every day is a parade of relatives and old friends.... That's why Sophie Anderson went back home.... She liked the slower pace of life of the South.... In Houston and Galveston, and way down in Louisiana, life was a little more aimless. People worked a little job but they couldn't make any real money no matter what they did. But in Los Angeles you could make a hundred dollars in a week if you pushed.... There's no time to walk down the 
street or make bar-b-q when somebody's going to pay you real money to haul refrigerators. (Mosley 49)

The aforementioned Sophie Anderson returns to Texas because she concludes that "L.A. is too much" (107). Easy himself has a love-hate relationship with Los Angeles. At times of intense pressure he is ready to concur with Sophie that "L.A. is too much," but on the whole for him L.A. symbolizes empowerment, advancement to middle class status and proprietorship: "Just to look out on Los Angeles at night gave me a sense of power" (92).

African Americans hoped to find a similar sense of empowerment by serving in the American armed forces during World War II. Facing constant questioning of his manhood in Texas, Easy joins the army to prove to himself more than to others that he is a man. His war-time experience exposes the concept of "white blood" and the various fears of white people. Rather than allow African American soldiers to participate in real combat, white commanders make them perform adjunct activities such as typing, afraid that African Americans will discover that they are capable of fighting and feel encouraged to fight for their own rights on their home turf in the United States. Easy also suspects that whites keep black soldiers away from actual combat because they want to deter black soldiers from "spill[ing] white blood" (98). Those whites who follow this kind of logic choose racial over national identification, clearly setting African Americans apart from other Americans. While Easy seeks the assertion of his manhood in the army, most black people joined the army in the hope of being fully integrated into the fabric of society. The participation of African Americans in World War II increased their hopes of enfranchisement, hopes that were dashed immediately after the war.

Easy's wartime experience prepares him for his future interactions with white people, but it does not eliminate an essentially physiological response that most of the encounters with whites elicit in him. This is how he responds to Albright before finding out that Albright is someone to dread: "When he looked at me I felt a thrill of fear, but that went away quickly because I was used to white people by 1948" (1). A very similar reaction to whiteness is at play when Easy declares that in the presence of white people he habitually "empt[ies] [his] head of everything" because "the less you know the less trouble you find" (13). Apart from blaming whites for the enforced silence, he also blames himself and the black community: "I hated myself for it but I also hated white people, and colored people too, for making me that way" (13). Shifting part of the blame for his silence or his fact-twisting in the presence of whites to the black community indicates that the distrust of whites is not only derived from 
his own experience, but also from the communal knowledge passed from generation to generation. Whites are approached as a separate tribe, which is probably most evident in the passage depicting Albright's treatment of racist white youths. Easy's primary fear is that if Albright treats a white person with no scruples, he will be capable of even greater cruelty towards an African American: "I cared that if Albright could do something like that to one of his own then I knew he could do the same, and much worse, to me" (57). The phrase "his own" resounds the term applied by Easy's racist employer, Giacomo, who tells Easy that "[his] people should learn to give a little extra if [they] wanna advance" (29). In both cases identity politics are at play, but power dynamics are also different in both cases because unlike Giacomo, Easy does not speak from a position of power.

Like other so-called ethnic American authors, Walter Mosley closely associates whiteness with death, not only by portraying white characters as avatars of death for African American characters, but also by directly ascribing death-like features to white characters in the novel. Easy's friend, Mouse, identifies the face of death which he claims to see in his drunken stupor as white (34). Apart from looking down on "white men with dead blue eyes" (63), Easy defines a phenotypically white character of biracial origin, Daphne Monet, as strongly evocative of death and therefore not worthy of emotional attachment: "I didn't really want her to stay. Daphne Monet was death herself. I was glad that she was leaving” (204). The white character mentioned above, Todd Carter, even has death hidden in his name, since in German "Todd" means death.

Mosley's Devil in a Blue Dress offers a multifaceted critique of the oppressive faces of whiteness, including the criticism of whiteness operating outside the fringes of the law, whiteness representing the law and the penal system, whiteness organizing labour relations in the United States, as well as mapping out the urban landscape of Los Angeles. Easy's encounters with representatives of each of these groups mark him negatively, either leaving an imprint on his body or posing a threat to his life, economic security and his mental integrity. The sinister faces of whiteness recurring throughout the novel inevitably lead to the scathing portrayal of whiteness that emerges from the narrative, both on the diegetic level and the level of the imagery suffused mostly with pejorative associations of whiteness.

\section{WORKS CiTED}

Berger, Roger A. “'The Black Dick': Race, Sexuality, and Discourse in the L.A. Novels of Walter Mosley.” African American Review 31.2 (1997): 281-94. Print. 
Berrettini, Mark L. "Private Knowledge, Public Space: Investigation and Navigation in Devil in a Blue Dress." Cinema Journal 39.1 (Autumn 1999): 74-89. Print.

Chesnutt, Charles Waddell. "The Passing of Grandison." Call and Response: The Riverside Anthology of African American Literary Tradition. Ed. Patricia Hill. Boston: Houghton Mifflin, 1998. Print.

Du Bois. W. E. B. Black Reconstruction. New York: Russell, 1963. Print.

---. “The Souls of White Folk.” Writings. Ed. Nathan Huggins. New York: Library of America, 1986. 923-38. Print.

Ellison, Ralph. Invisible Man. New York: Vintage, 1972. Print.

Frankenberg, Ruth. "Whiteness and Americanness: Examining Constructions of Race, Culture, and Nation in White Women's Life Narratives.” Race. Ed. Steven Gregory and Roger Sanjek. New Brunswick: Rutgers UP, 1994. 62-77. Print.

Harris, Cheryl. "Whiteness as Property." The Harvard Law Review 106.8 (1993): 1709-91. Print.

Kennedy, Liam. "Black Noir: Race and Urban Space in Walter Mosley's Detective Fiction." Diversity and Detective Fiction. Ed. Kathleen Gregory Klein. Bowling Green, OH: Bowling Green State U Popular P, 1999. 224-39. Print.

King, Nicole. “'You Think like You White': Questioning Race and Racial Community through the Lens of Middle-Class Desire(s)." Novel: A Forum on Fiction 35.2\&3 (2002): 211-30. Print.

Lipsitz, George. The Possessive Investment in Whiteness. How White People Profit From Identity Politics. Philadelphia: Temple UP, 1998. Print.

Mason, Theodore. "Walter Mosley's Easy Rawlins: The Detective and Afro-American Fiction." The Kenyon Review 14.4 (1992): 173-83. Print.

McLaren, Peter. "White Terror and Oppositional Agency: Towards a Critical Multiculturalism." Multiculturalism. A Critical Reader. Ed. David Theo Goldberg. Oxford: Blackwell, 1995. 46-73. Print.

Morrison, Toni. Playing in the Dark. Whiteness and Literary Imagination. Cambridge: Harvard UP, 1992. Print.

Mosley, Walter. Black Betty. New York: Washington Square P, 1994. Print. ---. Devil in a Blue Dress. New York: Pocket, 1990. Print.

Prashad, Vijay. Everybody was Kung Fu Fighting: Afro-Asian Connections and the Myth of Cultural Plurality. Boston, MA: Beacon, 2001. Print.

Roediger, David. The Wages of Whiteness: Race and the Making of the American Working Class. London: Verso, 1991. Print.

Stein, Thomas Michael. “The Ethnic Vision in Walter Mosley's Crime Fiction." Americastudien/American Studies 39.2 (1994): 197-212. Print. 
Szmańko, Klara. Visions of Whiteness in Selected Works of Asian American Literature. Jefferson, NC: McFarland, 2015. Print.

Wesley, Marilyn C. "Power and Knowledge in Walter Mosley's Devil in a Blue Dress." African American Review 35.1 (Spring 2001): 103-16. Print.

Wiegman, Robyn. "Whiteness Studies and the Paradox of Particularity." boundary 226.3 (1999): 115-50. Print.

Klara SzmańKO is Associate Professor at the Department of English, University of Opole. She specializes in American ethnic literature, in particular African American and Asian American literature. The recurring tropes of her publications are whiteness, invisibility, visibility, visual dynamics, power dynamics, transformational identity politics, multiculturalism, representation of space, mimicry, nationalism and gender relations. She is also the author of two monographs published in the United States: Invisibility in African American and Asian American Literature: A Comparative Study (2008) and Visions of Whiteness in Selected Works of Asian American Literature (2015). Klara Szmańko did her MA (2002), as well as $\mathrm{PhD}$ (2005) at the University of Wrocław, and her habilitation at the University of Łódź in 2016.

klarka@op.pl 